\title{
GIORGIO AGAMBENS POLITISKE FILOSOFI
}

Rasmus Ugilt:

Giorgio Agamben: Political Philosophy,

Humanities-Ebooks, 2014

122 sider, $£ 3,99$ (PDF/Ebook), $£ 9.99$ (paperback)

I sin lille bog om Giorgio Agambens politiske filosofi forsøger Rasmus Ugilt at sammenfatte og udlægge Agambens politisk-filosofiske projekt, særligt som det kommer til udtryk i Homo Sacer-projektet. Ugilt fokuserer derfor også hovedsageligt på tre afgørende værker i projektet: Homo Sacer - Den suveræne magt og det nøgne liv (1995), Undtagelsestilstand (2005, udgivet på dansk på Forlaget Philosophia, 2009) og Riget og herligheden (2007). Når man hører begrebet politisk filosofi, tænker man det nok normalt netop som en politisk filosofi, men Ugilts pointe i forhold til Agamben er, at han må læses som politisk filosofi (eller nok nærmere som politisk filosofi eftersom der for Agamben ikke ville være en central adskillelse mellem de to). Ugilts centrale pointe er således, at man først og fremmest må forstå Agamben som filosof, som er interesseret i klassiske filosofiske spørgsmål såsom 'hvad er væren?', 'hvad er et menneske?', 'hvad er livet?', 'hvad er lov?' og 'hvad er retfærdighed?'. Agambens (politiske) projekt er, ifølge Ugilt, "helt igennem filosofisk" (s. 52).

Agamben er blevet meget kendt og er meget (om)diskuteret i dag, særligt i forhold til sine provokerende teser om at vi lever i en permanent undtagelsestilstand, under (KZ-)lejrens logik, hvor alt liv er reduceret til nøgent liv uden rettigheder. Ugilt forsøger derimod at hæve Agambens politiske projekt over disse analyser, og vise, at Agamben ikke er så obskur, som han ofte anklages for at være, men at hans projekt derimod angår en total omstrukturering af den moderne politiske tænkning. Derfor angriber han også politiske problemstillinger på en andre måder end de sædvanlige. Agamben er interesseret i at undersøge de fundamentale problemer i vores nuværende politiske situation. Disse problemer er for Agamben (ifølge Ugilt) uløseligt forbundet med centrale, klassiske filosofiske spørgsmål, og Ugilt strukturerer derfor bogen omkring det, han mener, er det centrale tema i Agambens tænkning: ontologi. Dette er ifølge Ugilt den bedste måde, hvorpå man kan forstå Agambens tænkning eller (politiske) filosofi som 
et sammenhængende hele, og bogens introduktion hedder således også 'Ontologi som politisk teori'.

Ontologi er den mest fundamentale filosofiske disciplin, og omhandler spørgsmålet om væren qua væren eller væren som væren (ifølge Aristoteles, som Agamben i mange henseender trækker meget på), og er dermed netop ikke biologi (der undersøger væren som levende væren) eller fysik (der undersøger væren som fysisk væren). Det centrale er, at væren som væren ikke skal forstås som værende en ting eller en entitet (som væren som fysisk eller levende væren), men som potentialitet (en kategori Agamben også henter fra Aristoteles). Med inspiration fra Martin Heidegger, anskuer Agamben det således, at vi omgiver os med en masse 'ting', som er (har væren), men som ikke i egentlig forstand kan betegnes som ting (forstået som havende fysisk eller levende eksistens). Sådanne ting er f.eks. lov og magt. Lov er selvfølgelig fysisk i det, at den er skrevet ned, og på mange måder kan man sige, at nogen har magt, men det ville være en meget dårlig forståelse af magt og lov, hvis man forstod dem (udelukkende) på denne måde (på denne måde er Agamben også inspireret af Michel Foucault og dennes fokus på magtens virken). Agambens pointe er, ifølge Ugilt, og her følger Agamben en række andre franske og italienske nulevende filosoffer, særligt Antonio Negri og Alain Badiou, at politik og ontologi er tæt forbundne. De kan faktisk ikke adskilles, og en undersøgelse af (politisk) ontologi er således allerede en politisk praksis. Det er derfor Agamben er interesseret $\mathrm{i}$ at undersøge helt fundamentale kategorier, netop fordi forståelsen eller udredelsen af sådanne kategorier i sig selv er en politisk praksis. Agamben (sammen med bevægelser i fransk filosofi i den sidste halvdel af det 20. århundrede) afviser således den fundamentale og almindelige distinktion mellem væren og handling, og hævder, at ontologiske kategorier er afgørende for at forstå politik. Der er derfor, for Agamben, ikke nogen essentiel forskel på eller distinktion mellem hvad noget 'er' og hvad noget 'gør'. Det er ikke sådan, at der 'er' sådan noget som 'væren', 'mennesker,' 'magt' eller 'lov' som så handler på en særlig måde, men selve den måde de handler på er med til at konstituere dem, og er en (hvis ikke den) afgørende bestanddel af, hvad de 'er'. Der er derfor ikke noget sådan som en 'menneskelig væren' som handler på en særlig måde, og Agamben hævder således, ifølge Ugilt, at der ikke er noget solidt ontologisk fundament, men at det ontologiske fundament $\mathrm{i}$ stedet er det Agamben kalder en 'uskelnelighedszone' eller 'ubestemmelighedszone' (zone of indistinction). Med en undersøgelse af Agambens forståelse af potentialitet 
som impotentialitet i kapitel 1 (Potentiel ontologi) argumenterer Ugilt for, at det er denne kategori om impotentialitet Agamben udleder fra en særegen (og på mange måder kontroversiel) læsning af Aristoteles, som gør det muligt for Agamben at introducere 'uskelnelighedszonen' som ontologisk grundkategori.

Det er denne forståelse af Agamben, som Ugilt derefter gennemfører i sin læsning af tre centrale værker i Agambens Homo Sacer-projekt. Bogen fungerer derfor både som en introduktion til centrale dele af Agambens forfatterskab, men også til en særlig læsning af Agamben. Som sådan er den interessant for både den indviede Agamben-læser, men også som en introduktion til Agambens (politisk) filosofiske projekt (omend nogle passager, særligt i kapitel 1 om potentiel ontologi, ikke er helt nemme for den uindviede eller ikke filosofisk trænede). Bogen er ret kort, hvilket både er en styrke, men som også kunne kritiseres for at være en svaghed eftersom den derfor nødvendigvis må udelade centrale ting. Pointen er dog klar: det er en læsning af Agamben som filosof, med særligt fokus på hans forståelse af ontologi, og det er denne læsning der gennemføres i tre centrale værker.

Hvis man skulle være meget kritisk, kunne man hævde, at bogen sætter sig lidt mellem to stole eftersom den netop både er en læsning og en introduktion, hvilket gør, at analysen af Agamben som filosof med en særlig forståelse af ontologi ikke gennemføres tilstrækkeligt fuldt ud i de enkelte værklæsninger. F.eks. kunne en sådan insisteren i forhold til Riget og herligheden (2007, eng. The Kingdom and the Glory) have været interessant i forhold til et endnu skarpere fokus på regeringsmaskinens dobbelte struktur i både en politisk teologi og en økonomisk teologi. Således kunne den ontologiske kategori om 'uskelnelighedszonen' mellem suverænitet og regering være blevet demonstreret ved ikke at fokusere på den økonomiske teologi og regeringen som magtens sted. Men det er en meget lille ting. Alt i alt en meget interessant læsning og gennemgang af Agambens værk for både de indviede og de uindviede.

Mathias Hein Jessen 